\title{
EFFECTS OF MANAGEMENT PRACTICES ON GRASSLAND BIRDS:
}

\section{LARK BUNTING}

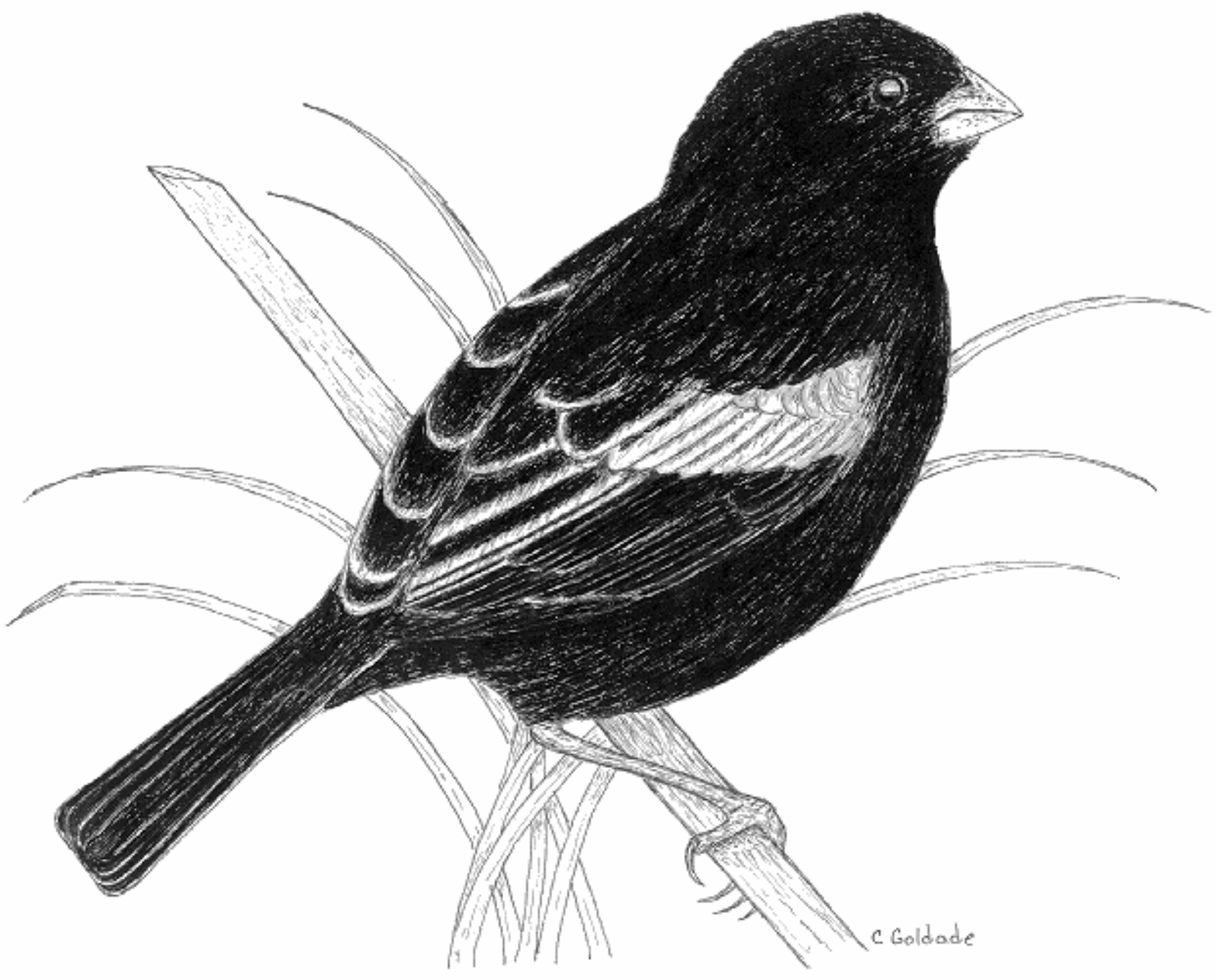

Grasslands Ecosystem Initiative

Northern Prairie Wildlife Research Center

U.S. Geological Survey

Jamestown, North Dakota 58401 
This report is one in a series of literature syntheses on North American grassland birds. The need for these reports was identified by the Prairie Pothole Joint Venture (PPJV), a part of the North American Waterfowl Management Plan. The PPJV recently adopted a new goal, to stabilize or increase populations of declining grassland- and wetland-associated wildlife species in the Prairie Pothole Region. To further that objective, it is essential to understand the habitat needs of birds other than waterfowl, and how management practices affect their habitats. The focus of these reports is on management of breeding habitat, particularly in the northern Great Plains.

Suggested citation:

Dechant, J. A., M. L. Sondreal, D. H. Johnson, L. D. Igl, C. M. Goldade, A. L. Zimmerman, and B. R. Euliss. 1999 (revised 2002). Effects of management practices on grassland birds: Lark Bunting. Northern Prairie Wildlife Research Center, Jamestown, ND. 18 pages.

Species for which syntheses are available or are in preparation:

American Bittern

Mountain Plover

Marbled Godwit

Long-billed Curlew

Willet

Wilson's Phalarope

Upland Sandpiper

Greater Prairie-Chicken

Lesser Prairie-Chicken

Northern Harrier

Swainson's Hawk

Ferruginous Hawk

Short-eared Owl

Burrowing Owl

Horned Lark

Sedge Wren

Loggerhead Shrike

Sprague's Pipit
Grasshopper Sparrow

Baird's Sparrow

Henslow's Sparrow

Le Conte's Sparrow

Nelson's Sharp-tailed Sparrow

Vesper Sparrow

Savannah Sparrow

Lark Sparrow

Field Sparrow

Clay-colored Sparrow

Chestnut-collared Longspur

McCown's Longspur

Dickcissel

Lark Bunting

Bobolink

Eastern Meadowlark

Western Meadowlark

Brown-headed Cowbird 


\section{EFFECTS OF MANAGEMENT PRACTICES ON GRASSLAND BIRDS:}

\section{LARK BUNTING}

Jill A. Dechant, Marriah L. Sondreal, Douglas H. Johnson, Lawrence D. Igl, Christopher M. Goldade, Amy L. Zimmerman, and Betty R. Euliss

Series Coordinator: Douglas H. Johnson

Series Assistant Coordinator: Lawrence D. Igl

Reviewer: Thomas G. Shane

Range Map: Jeff T. Price

Cover Art: Christopher M. Goldade

Major Funding: Prairie Pothole Joint Venture, U.S. Fish and Wildlife Service U.S. Geological Survey

Funding also provided by: U.S. Forest Service

\section{Collaborators:}

Louis B. Best, Iowa State University

Carl E. Bock, University of Colorado

Brenda C. Dale, Canadian Wildlife Service

Stephen K. Davis, Saskatchewan Wetland Conservation Corporation

James J. Dinsmore, Iowa State University

James K. Herkert, Illinois Endangered Species Protection Board

Fritz L. Knopf, Midcontinent Ecological Science Center

Rolf R. Koford, Iowa Cooperative Fish and Wildlife Research Unit

David R. C. Prescott, Alberta NAWMP Centre

Mark R. Ryan, University of Missouri

David W. Sample, Wisconsin Department of Natural Resources

David A. Swanson, Ohio Division of Wildlife

Peter D. Vickery, Massachusetts Audubon Society

John L. Zimmerman (retired), Kansas State University 


\section{ORGANIZATION AND FEATURES OF THIS SPECIES ACCOUNT}

Information on the habitat requirements and effects of habitat management on grassland birds were summarized from information in more than 4,000 published and unpublished papers. A range map is provided to indicate the relative densities of the species in North America, based on Breeding Bird Survey (BBS) data. Although birds frequently are observed outside the breeding range indicated, the maps are intended to show areas where managers might concentrate their attention. It may be ineffectual to manage habitat at a site for a species that rarely occurs in an area. The species account begins with a brief capsule statement, which provides the fundamental components or keys to management for the species. A section on breeding range outlines the current breeding distribution of the species in North America, including areas that could not be mapped using BBS data. The suitable habitat section describes the breeding habitat and occasionally microhabitat characteristics of the species, especially those habitats that occur in the Great Plains. Details on habitat and microhabitat requirements often provide clues to how a species will respond to a particular management practice. A table near the end of the account complements the section on suitable habitat, and lists the specific habitat characteristics for the species by individual studies. A special section on prey habitat is included for those predatory species that have more specific prey requirements. The area requirements section provides details on territory and home range sizes, minimum area requirements, and the effects of patch size, edges, and other landscape and habitat features on abundance and productivity. It may be futile to manage a small block of suitable habitat for a species that has minimum area requirements that are larger than the area being managed. The Brown-headed Cowbird (Molothrus ater) is an obligate brood parasite of many grassland birds. The section on cowbird brood parasitism summarizes rates of cowbird parasitism, host responses to parasitism, and factors that influence parasitism, such as nest concealment and host density. The impact of management depends, in part, upon a species' nesting phenology and biology. The section on breeding-season phenology and site fidelity includes details on spring arrival and fall departure for migratory populations in the Great Plains, peak breeding periods, the tendency to renest after nest failure or success, and the propensity to return to a previous breeding site. The duration and timing of breeding varies among regions and years. Species' response to management summarizes the current knowledge and major findings in the literature on the effects of different management practices on the species. The section on management recommendations complements the previous section and summarizes specific recommendations for habitat management provided in the literature. If management recommendations differ in different portions of the species' breeding range, recommendations are given separately by region. The literature cited contains references to published and unpublished literature on the management effects and habitat requirements of the species. This section is not meant to be a complete bibliography; a searchable, annotated bibliography of published and unpublished papers dealing with habitat needs of grassland birds and their responses to habitat management is posted at the Web site mentioned below.

This report has been downloaded from the Northern Prairie Wildlife Research Center WorldWide Web site, www.npwrc.usgs.gov/resource/literatr/grasbird/grasbird.htm. Please direct comments and suggestions to Douglas H. Johnson, Northern Prairie Wildlife Research Center, U.S. Geological Survey, 8711 37th Street SE, Jamestown, North Dakota 58401; telephone: 701253-5539; fax: 701-253-5553; e-mail: Douglas_H_Johnson@usgs.gov. 


\section{LARK BUNTING}

(Calamospiza melanocorys)

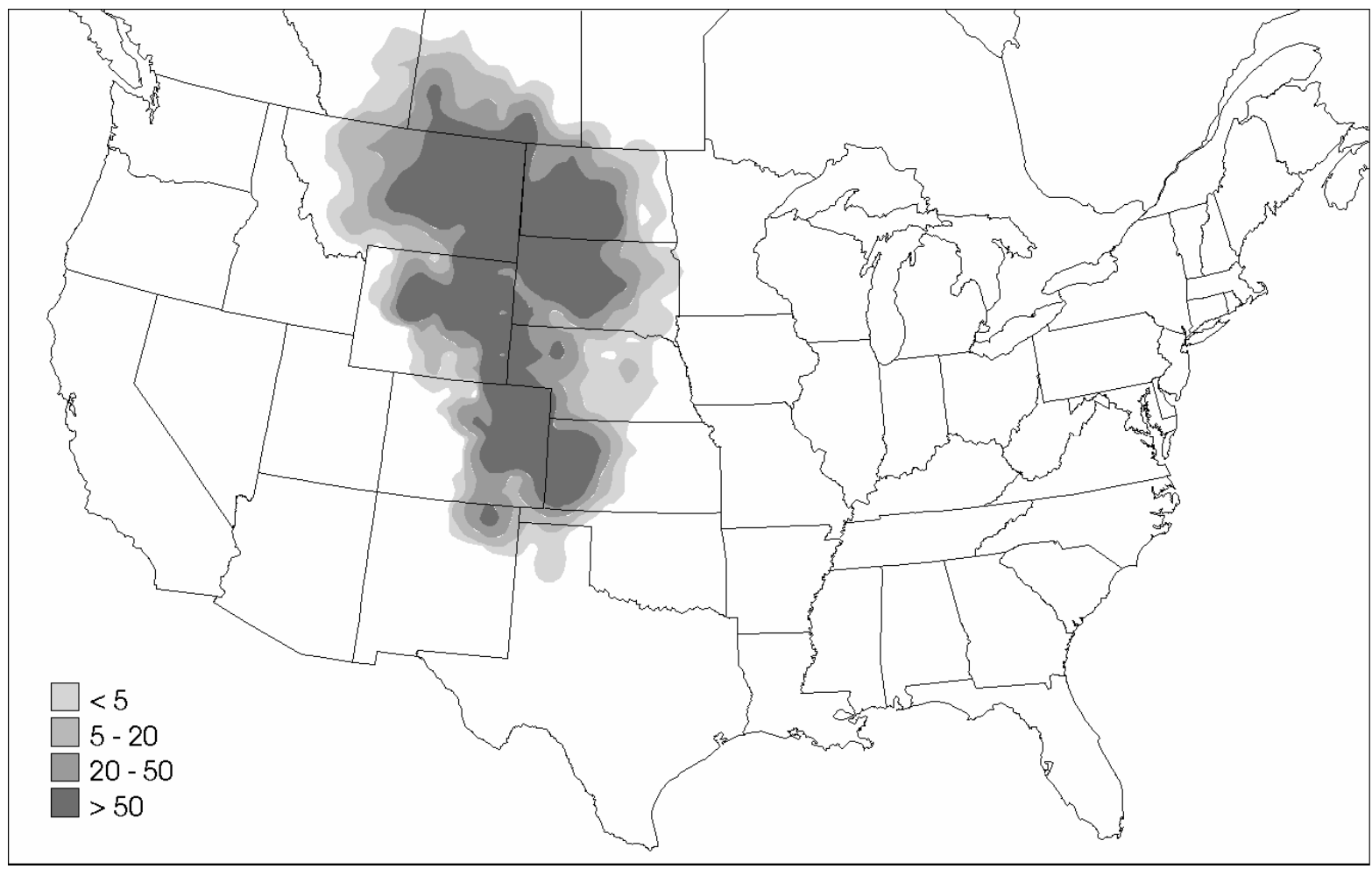

Figure. Breeding distribution of the Lark Bunting in the United States and southern Canada, based on Breeding Bird Survey data, 1985-1991. Scale represents average number of individuals detected per route per year. Map from Price, J., S. Droege, and A. Price. 1995. The summer atlas of North American birds. Academic Press, London, England. 364 pages.

Keys to management include providing short vegetation with protective nest cover and tailoring grazing systems and intensity to the type of grassland.

\section{Breeding range:}

Lark Buntings breed from southern Alberta through southern Manitoba, south to western New Mexico and western Texas, and east to eastern South Dakota and northwestern Missouri (National Geographic Society 1987). (See figure for the relative densities of Lark Buntings in the United States and southern Canada, based on Breeding Bird Survey data.)

\section{Suitable habitat:}

Lark Buntings use grasslands of low to moderate height $(\leq 60 \mathrm{~cm})$ with high (45\%) vegetative cover and 10-15\% bare ground (Smith and Smith 1966, Wiens 1970, Shane 1972, Creighton 1974), often with a superstory component such as shrubs (Baldwin et al. 1969, With and Webb 1993, Shane 2000). Shrubs are especially important in savanna and sagebrush (Artemisia) habitats (Woolfolk 1945). Shortgrass prairie, mixed-grass prairie, and shrubsteppe habitats support Lark Bunting populations, as do weedy fallow croplands, minimum-tillage croplands, planted cover (e.g., Conservation Reserve Program [CRP] fields and Permanent Cover Program [PCP] fields), legume haylands, and pastures planted to either native or tame 
grasses (Cameron 1908; Shane 1972, 2000; Wiens 1973; Creighton 1974; Maher 1974; Porter and Ryder 1974; Fautin 1975; Stewart 1975; Johnsgard 1980; Pleszczynska and Hansell 1980; Johnson 1981; Kantrud 1981; Kantrud and Kologiski 1983; Dunn 1986; Johnson and Schwartz 1993a,b; Davis et al. 1997; Lokemoen and Beiser 1997; McMaster and Davis 1998). Rotenberry and Wiens (1980) found that abundance of Lark Buntings in parts of Colorado, Kansas, Montana, Nebraska, Oklahoma, South Dakota, Texas, and Wyoming was correlated positively with litter depth. Breeding Bird Survey data indicated that Lark Buntings preferred areas $\geq 10$ $\mathrm{km}^{2}$ dominated by wheatgrass (Agropyron spp.), blue grama (Bouteloua gracilis), needle-andthread (Stipa comata), and big sagebrush (Artemisia tridentata) (Shane 2000). In portions of Colorado, Kansas, Minnesota, Nebraska, North Dakota, Oklahoma, South Dakota, and Texas, Lark Buntings nested in mixed-grass and shortgrass areas and areas dominated by sagebrush; they also used taller grass areas with scattered shrubs, weedy edges, retired cropland, and alfalfa (Medicago sativa) or clover (Trifolium) fields (Johnsgard 1979, 1980; Shane 2000). Faanes and Lingle (1995) reported similar nesting requirements in Nebraska. They found Lark Buntings nesting in mixed-grass and shortgrass areas, wet meadow, wheat, and alfalfa fields; buntings preferred shrub-dominated grasslands. In North Dakota, Lark Buntings preferred areas of sage flats along stream valleys or in lowland draws (Stewart 1975). They also used weedy roadsides, retired cropland planted to grasses and legumes, weedy fallow fields, and alfalfa hayland. In Wyoming, Lark Buntings occurred more frequently in areas dominated by sagebrush than areas where only grass and cactus (Opuntia) were present (Fautin 1975).

Lark Buntings often build nests under protective vegetation, including forbs, tall grasses, low shrubs, and cacti (Whittle 1922; Woolfolk 1945; Baumgarten 1968; Baldwin et al. 1969; Creighton 1971; Shane 1972, 2000; Stewart 1975; Wilson 1976; Pleszczynska 1977; Johnsgard 1979). In South Dakota, nests were located under plants such as alfalfa, fringed sagewort (Artemisia frigida), plains prickly pear cactus (Opuntia polyacantha), and soapweed yucca (Yucca glauca) (Pleszczynska 1977). In Montana, nests were in weedy areas beneath tumble ringwing (Cycloloma atriplicifolium) (Whittle 1922) and under sagebrush (Woolfolk 1945). In Oklahoma, Lark Buntings nested among grama (Bouteloua spp.) grasses, buffalo grass (Buchloe dactyloides), yucca (Yucca sp.), sand sagebrush (Artemisia filifolia), and various forb species (Dunn 1986). In Colorado, Lark Buntings were associated with slimspike three-awn (Aristida longiseta), four-wing saltbush (Atriplex canescens), and rabbitbrush (Chrysothamnus nauseosus) (Baldwin et al. 1969, Creighton 1974). In Saskatchewan, nests were placed under western snowberry (Symphoricarpos occidentalis) (Smith and Smith 1966). Vegetative cover may provide protection from inclement weather and from depredation (Woolfolk 1945, Baumgarten 1968, Baldwin et al. 1969, Strong 1971, Creighton 1974, Pleszczynka 1977, With and Webb 1993, Shane 2000), as well as provide open views in one or more directions (Baldwin et al. 1969, Shane 1972, Wilson 1976). The presence of protective cover may be a major factor in reproductive success (Strong 1971, Pleszczynska 1977).

In Kansas, Lark Buntings oriented nests adjacent to protective vegetation that allowed access to morning sunlight, adequate ventilation, and afternoon shade (Shane 1974, 2000). In Colorado shortgrass pasture, the majority of nests were placed on the northern side of vegetation (With and Webb 1993). In other studies, nests were placed on the east or southeast side of protective vegetation (Baldwin et al. 1969, Creighton 1971, Pleszczynska 1977). 
Time of season may influence selection of nesting habitat. In Kansas, Lark Buntings used stubble fields for nesting during the early part of the breeding season, and later nested in native grassland on hillsides with sparser vegetation (Wilson 1976).

Mean height of vegetation around ground nests in Colorado (Baldwin et al. 1969), Kansas (Shane 1972), and Utah (Johnson 1981) ranged from 15 to $28 \mathrm{~cm}$. In Saskatchewan, nests in mixed-grass pasture were placed on the ground in vegetation 18 to $61 \mathrm{~cm}$ tall (Smith and Smith 1966). In sand sagebrush grasslands in Kansas, areas in which nests were found had fewer and shorter sand sagebrush plants and had higher percent forb cover (mean of 48.2\%) than areas where nests were not present (Shane 1972). Successful nests (those with young present $6 \mathrm{~d}$ after hatching) were adjacent to tall (mean of $30.6 \mathrm{~cm}$ ) overall vegetation and tall (mean of 41.9 $\mathrm{cm}$ ) forbs. A table near the end of the account lists the specific habitat characteristics for Lark Buntings by study.

\section{Area requirements:}

Territory size in northcentral Colorado was 0.5-1.1 ha (Wiens 1970, 1971; Finch et al. 1987). In South Dakota, territory size averaged about 0.2 ha in idle mixed-grass and alfalfa fields (Pleszczynska 1977). However, territory size may be difficult to measure because unmated males will display within other males' territories (Finch et al. 1987). Lark Buntings may be area sensitive; they have been associated with large areas of contiguous grassland (D. H. Johnson, unpublished data). Shane (2000) reported that Lark Buntings preferred patches $>10$ $\mathrm{km}^{2}$. For Lark Bunting, no studies have investigated a relationship between patch size and nest success or patch size and rates of brood parasitism by Brown-headed Cowbirds (Molothrus ater).

\section{Brown-headed Cowbird brood parasitism:}

Generally, Lark Bunting nests are parasitized infrequently by Brown-headed Cowbirds; however, they may be common hosts in local situations (Friedmann 1963, Friedmann et al. 1977). Parasitism rates vary from $0 \%$ of 30 nests (Shane 2000) to $61 \%$ of 23 nests (Koford et al. 2000). Refer to Table 1 in Shaffer et al. 2003 for rates of cowbird brood parasitism. Lark Buntings may be multiply-parasitized (Allen 1874, Knapton 1979, Davis and Sealy 2000). In Kansas, Lark Buntings were unimportant hosts because of loss of nests to farming operations, ejection of cowbird eggs, and desertion of parasitized nests by parents (Hill 1976). Furthermore, in Kansas (Wilson 1976) and Manitoba (Davis 1994, Davis and Sealy 2000), Lark Buntings with parasitized nests failed to fledge any Brown-headed Cowbird young. In Saskatchewan, Sealy (1999) reported that of nine Brown-headed Cowbird eggs found in five nests, seven eggs were accepted and two eggs were buried in nest lining. Of the remaining seven nests, cowbirds were found in the nestling stage. Of five artificially parasitized nests, cowbird eggs were accepted in four nests. The cowbird egg disappeared within $24 \mathrm{hr}$ from the fifth nest, which was naturally parasitized $3 \mathrm{~d}$ after the experimental egg disappeared. The naturally laid cowbird egg hatched.

Breeding-season phenology and site fidelity:

The breeding season extends from early May to early August, although Lark Buntings still may be present on the breeding grounds later in the season (Cameron 1908, Baumgarten 1968, Giezentanner and Ryder 1969, Creighton 1971, Maher 1974, Wilson 1976, Knapton 1979, Johnson 1981, Shane 2000). In Kansas, males arrived on the breeding grounds 1-8 d earlier than females and acquired territories (Shane 2000). In North Dakota, peak breeding occurs from 
early June to early August (Stewart 1975). Strong (1971) reported that Lark Buntings produced single broods; however, Langdon (1933) and Shane (2000) indicated that Lark Buntings were sometimes double-brooded. Lark Buntings usually renest after loss of the initial nest (Shane 2000).

Lark Buntings may exhibit site fidelity. In Colorado, a male bunting was recaptured three years later in the same general area in which he was banded (Klimkiewicz and Futcher 1987). Also in Colorado, two birds were recaptured in the same location in which they were banded the previous year, and a female returned the two years following banding to within 0.8 $\mathrm{km}$ of where she was initially banded (Ryder 1972).

\section{Species' response to management:}

Management and monitoring may be difficult on the periphery of the species' breeding range, as Lark Buntings fluctuate locally in numbers from year to year because of irruptive migration (Hibbard 1965, Baumgarten 1968, Wilson 1976), which may be related to annual variation in precipitation (Tout 1902). Little information is available about the effects of burning on Lark Buntings. In southcentral Montana, Lark Buntings avoided burned areas where brush cover had been eliminated (Bock and Bock 1987). In Nebraska, Lark Buntings were present in pastures that were both grazed by American bison (Bison bison) and burned; they were not present in cattle-grazed areas (Griebel et al. 1998).

In portions of Montana, North Dakota, and South Dakota, Lark Bunting density was lower in CRP fields with greater coverage of legumes (Johnson and Schwartz 1993b), and in North Dakota, the species avoided haylands that were mowed the previous year (Kantrud 1981). However, in Saskatchewan, Lark Buntings bred only in cultivated haylands and rarely used native grasslands (Maher 1974). In Kansas, higher nest success was reported in native grassland and alfalfa than in milo stubble fields; no young fledged from nests in seeded pasture (native or tame not specified) (Wilson 1976). Direct effects of mowing during the breeding season are not well known specifically for the Lark Bunting, but likely include lower productivity due to mortality of eggs and nestlings.

Grazing effects on Lark Buntings vary depending on grassland type and intensity. In shortgrass prairie, heavy grazing often is detrimental to Lark Buntings because it increases bare ground cover, reduces vegetation height, and removes protective cover (Rand 1948, Ryder 1980, Bock et al. 1993). In shortgrass and shrubsteppe habitats in northcentral Colorado, lightly to moderately grazed areas were preferred over heavily grazed areas (Giezentanner 1970, Strong 1971, Porter and Ryder 1974, Ryder 1980, Bock et al. 1993). Lark Buntings preferred nesting in pasture that was lightly grazed in the summer, followed by pasture that was heavily or moderately grazed in winter, and pasture that was moderately grazed in summer; they were absent from pasture heavily grazed in summer (Giezentanner and Ryder 1969; Giezentanner 1970; Wiens 1970, 1973). In mixed-grass prairie in North Dakota, Lark Buntings were attracted to moderately grazed areas (Kantrud 1981). In Colorado, Montana, Nebraska, North Dakota, South Dakota, and Wyoming, densities of Lark Buntings were lowest on heavily grazed, warm, dry ustic aridisoll soils; densities were unaffected by cool, moist, typic boroll soils (Kantrud and Kologiski 1982). Densities were highest on heavily grazed, warm, moist, typic ustoll soils and on moderately or heavily grazed, cool, moderate to dry, aridic boroll soils and borollic aridisol soils. Finch et al. (1987) suggested that heavy grazing in vegetation $>30 \mathrm{~cm}$ tall would provide suitable habitat for breeding Lark Buntings. 
Lark Buntings are common in CRP and PCP grasslands (Johnson and Schwartz 1993a,b; McMaster and Davis 1998). PCP was a Canadian program that pays farmers to seed highly erodible land to perennial grassland cover; it differed from CRP in the United States in that haying and grazing were allowed annually in PCP. In aspen parkland in Alberta, Manitoba, and Saskatchewan, Lark Buntings were more common in PCP grasslands than in cropland; frequency of occurrence did not differ between hayed and grazed PCP sites (McMaster and Davis 1998). In portions of Montana, North Dakota, and South Dakota, Lark Buntings were abundant in both native and tame CRP, although they were less common in areas with a high percent coverage of grasses and legumes (Johnson and Schwartz 1993a,b).

In Nebraska, Lark Buntings occasionally nest in cropland (Faanes and Lingle 1995). The highest density of nests occurred in wheat, followed by shortgrass and mixed-grass prairie, alfalfa, and wet meadow. Although the highest breeding densities were in wheat stubble, it was noted that nests in that habitat may be destroyed by frequent disturbance. In North Dakota, Lark Buntings nested in minimum-tillage cropland (Lokemoen and Beiser 1997). Minimum tillage was defined as seeding into untilled or moderately tilled plant residue; weeds in crop fields were controlled by herbicides. Lark Buntings did not nest in conventionally-tilled cropland.

Conventional tillage was defined as tillage in spring and fall, with use of herbicides and tillage to control weeds.

In shortgrass prairie in Wyoming, diazinon applications for grasshopper (Orthoptera) control resulted in declines and mortality of Lark Buntings (McEwen et al. 1972). At the Pawnee National Grassland in Colorado, malathion and toxaphene were applied at rates of 0.6 $\mathrm{kg} / \mathrm{ha}$ and $1.1 \mathrm{~kg} / \mathrm{ha}$, respectively (McEwen and Ells 1975). Densities of Lark Buntings were highest in untreated grasslands than in grasslands treated with malathion or toxaphene.

\section{Management Recommendations:}

Provide large $\left(>10 \mathrm{~km}^{2}\right)$ grassland areas (Shane 2000). Relative densities of Lark Buntings increased with increasing area of contiguous grassland, and the species avoided small grassland patches (D. H. Johnson, unpublished data).

To prevent lowered productivity, use caution when studying Lark Buntings during the breeding season (Creighton 1971). Mammalian predators, such as thirteen-lined ground squirrels (Spermophilus tridecemlineatus), can follow researchers' scent trails to nests.

Avoid burning nesting habitat where all brush cover would be eliminated, particularly in areas where the Lark Bunting is largely associated with shrubs (Woolfolk 1945, Bock and Bock 1987). Lark Buntings avoided burned areas in Montana shrubsteppe after wildfire removed all brush (Bock and Bock 1987).

Delay mowing of hayfields until after the breeding season to prevent destruction of nests. Hayland may be an important habitat for Lark Buntings; hayland was preferred over uncultivated grassland in Saskatchewan (Maher 1974), and in Kansas hayland supported higher nest success than stubble fields (Wilson 1976). 
In shortgrass habitats, do not implement heavy grazing during the summer (Giezentanner 1970, Wiens 1973, Ryder 1980). In Colorado, Lark Buntings did not use heavily summer-grazed areas, but would use heavily winter-grazed areas for breeding (Ryder 1980). In shortgrass areas, lightly graze or graze during winter, provided that vegetative cover and height are not greatly reduced (Giezentanner 1970).

Allow heavy grazing in vegetation $>30 \mathrm{~cm}$ tall to provide the shorter, sparser habitat preferred by Lark Buntings (Finch et al. 1987).

Discing destroys nests and causes adult Lark Buntings to abandon the nesting area (Wilson 1976, Faanes and Lingle 1995). In North Dakota, Lark Buntings nested in cropland that was under minimum tillage (Lokemoen and Beiser 1997). No-tillage or minimum tillage is recommended as an alternative to fall cultivation.

When pest management is required, use only rapidly degrading chemicals of low toxicity to nontarget organisms and apply at the lowest application rates possible (McEwen et al. 1972). Maintain range in good condition; overgrazed and drought-affected areas are more prone to pest outbreaks. 
Table. Lark Bunting habitat characteristics.

\begin{tabular}{|c|c|c|c|}
\hline Author(s) & Location(s) & Habitat(s) Studied* & Species-specific Habitat Characteristics \\
\hline Baldwin et al. 1969 & Colorado & Shortgrass pasture & $\begin{array}{l}\text { Preferred habitat of brush and grass, followed by } \\
\text { shortgrass, then taller vegetation; most nests were in } \\
\text { vegetation that was } 15-28 \mathrm{~cm} \text { tall; nests were placed } \\
\text { under protective plants, majority of nests were on } \\
\text { the east side of vegetative cover }\end{array}$ \\
\hline Bock and Bock 1987 & Montana & $\begin{array}{l}\text { Burned shrubsteppe, } \\
\text { idle shrubsteppe }\end{array}$ & $\begin{array}{l}\text { Preferred shrubby areas; avoided shrubless, burned } \\
\text { areas }\end{array}$ \\
\hline Creighton 1971, 1974 & Colorado & $\begin{array}{l}\text { Mixed-grass pasture, } \\
\text { shortgrass pasture }\end{array}$ & $\begin{array}{l}\text { Used areas of moderate vegetation height (mean of } \\
13 \mathrm{~cm} \text { ) with about } 10-15 \% \text { bare ground and taller, } \\
\text { denser vegetation than surrounding shortgrass } \\
\text { habitat; used areas with } 8 \% \text { sedge cover, } 7 \% \text { forb } \\
\text { cover, } 2 \% \text { cactus cover, } 2 \% \text { shrub cover, and } 0.7 \% \\
\text { rock cover; often associated with slimspike three- } \\
\text { awn (Aristida longiseta), four-wing saltbush, and } \\
\text { rabbitbrush (Chrysothamnus nauseosus) }\end{array}$ \\
\hline Dunn 1986 & Oklahoma & Shortgrass pasture & $\begin{array}{l}\text { Nested among grama grasses (Bouteloua spp.) and } \\
\text { buffalo grass (Buchloe dactyloides) interspersed } \\
\text { with yucca (Yucca sp.), sand sagebrush (Artemesia } \\
\text { filifolia), and various forbs }\end{array}$ \\
\hline \multirow[t]{2}{*}{ Faanes and Lingle 1995} & Nebraska & $\begin{array}{l}\text { Cropland, idle mixed- } \\
\text { grass, idle shortgrass, } \\
\text { idle tallgrass, pasture, } \\
\text { tame hayland, wet } \\
\text { meadow, wetland, } \\
\text { woodland }\end{array}$ & $\begin{array}{l}\text { Nested in wheat, shortgrass and mixed-grass prairie, } \\
\text { alfalfa (Medicago sativa), and wet meadow; } \\
\text { preferred shrub-dominated grasslands }\end{array}$ \\
\hline & & & Occurred more frequently in areas dominated by \\
\hline
\end{tabular}




\begin{tabular}{|c|c|c|c|}
\hline Fautin 1975 & Wyoming & Shrubsteppe & $\begin{array}{l}\text { sagebrush than areas where only grass and cactus } \\
\text { (Opuntia) were present }\end{array}$ \\
\hline Giezentanner 1970 & Colorado & $\begin{array}{l}\text { Cropland, hayland, idle, } \\
\text { shortgrass pasture }\end{array}$ & $\begin{array}{l}\text { Preferred lightly grazed areas for nesting; avoided } \\
\text { heavily summer-grazed areas }\end{array}$ \\
\hline $\begin{array}{l}\text { Giezentanner and Ryder } \\
1969\end{array}$ & Colorado & Shortgrass pasture & $\begin{array}{l}\text { Preferred lightly summer-grazed pastures for } \\
\text { nesting, followed by heavily and moderately winter- } \\
\text { grazed pastures, and moderately summer-grazed } \\
\text { pastures; were absent from heavily summer-grazed } \\
\text { pastures }\end{array}$ \\
\hline Johnsgard 1979 & $\begin{array}{l}\text { Colorado, Kansas, } \\
\text { Minnesota, } \\
\text { Nebraska, North } \\
\text { Dakota, Oklahoma, } \\
\text { South Dakota, } \\
\text { Texas }\end{array}$ & $\begin{array}{l}\text { Cropland, idle, mixed- } \\
\text { grass prairie, shortgrass } \\
\text { prairie, tame hayland }\end{array}$ & $\begin{array}{l}\text { Nested in mixed- and shortgrass areas and areas } \\
\text { dominated by sagebrush (Artemisia); also used taller } \\
\text { grass areas with scattered shrubs, weedy edges, } \\
\text { retired cropland, and alfalfa or clover (Trifolium) } \\
\text { fields; nested on the ground, often at the base of a } \\
\text { shrub or coarse forb }\end{array}$ \\
\hline Johnsgard 1980 & Nebraska & $\begin{array}{l}\text { Cropland, idle, idle } \\
\text { mixed-grass, idle } \\
\text { shortgrass, idle } \\
\text { tallgrass, mixed-grass } \\
\text { pasture, tallgrass } \\
\text { pasture, tame hayland, } \\
\text { wet meadow }\end{array}$ & $\begin{array}{l}\text { Nested in mixed-grass, shortgrass, and areas } \\
\text { dominated by sagebrush; also used tallgrass areas } \\
\text { with scattered shrubs or weedy edges, retired } \\
\text { cropland, and alfalfa fields }\end{array}$ \\
\hline $\begin{array}{l}\text { Johnson and Schwartz } \\
1993 a, b\end{array}$ & $\begin{array}{l}\text { Minnesota, } \\
\text { Montana, } \\
\text { North Dakota, } \\
\text { South Dakota }\end{array}$ & $\begin{array}{l}\text { Conservation Reserve } \\
\text { Program (CRP; idle } \\
\text { seeded-native, idle } \\
\text { tame), cropland }\end{array}$ & $\begin{array}{l}\text { Were abundant in both native and tame CRP; were } \\
\text { less common in areas with high percent cover of } \\
\text { grasses and legumes }\end{array}$ \\
\hline Kantrud 1981 & North Dakota & $\begin{array}{l}\text { Mixed-grass hayland, } \\
\text { mixed-grass pasture }\end{array}$ & $\begin{array}{l}\text { Highest densities were in moderately grazed areas; } \\
\text { avoided hayland mowed the previous year }\end{array}$ \\
\hline
\end{tabular}




\begin{tabular}{|c|c|c|c|}
\hline $\begin{array}{l}\text { Kantrud and Kologiski } \\
\text { 1982, } 1983\end{array}$ & $\begin{array}{l}\text { Colorado, } \\
\text { Montana, } \\
\text { Nebraska, } \\
\text { North Dakota, } \\
\text { South Dakota, } \\
\text { Wyoming }\end{array}$ & $\begin{array}{l}\text { Mixed-grass pasture, } \\
\text { shortgrass pasture, } \\
\text { shrubsteppe }\end{array}$ & $\begin{array}{l}\text { Preferred heavily grazed native grasslands with } \\
\text { typic ustoll soils; favored moderately or heavily } \\
\text { grazed areas that had aridic boroll soils and borollic } \\
\text { aridisol soils; densities lowest on heavily grazed } \\
\text { grasslands with ustic aridisoll soils; grazing did not } \\
\text { influence densities on typic boroll soils; used } \\
\text { grasses 5-23 cm tall and usually avoided taller } \\
\text { grasses }\end{array}$ \\
\hline $\begin{array}{l}\text { Lokemoen and Beiser } \\
1997\end{array}$ & North Dakota & Cropland, idle & $\begin{array}{l}\text { Nested in minimum-tillage and organic fields, but } \\
\text { not in conventionally-tilled fields }\end{array}$ \\
\hline Maher 1974 & Saskatchewan & $\begin{array}{l}\text { Cropland, idle mixed- } \\
\text { grass, mixed-grass } \\
\text { pasture, tame hayland, } \\
\text { woodland }\end{array}$ & Bred only in hayland; were rare on native grassland \\
\hline McMaster and Davis 1998 & $\begin{array}{l}\text { Alberta, Manitoba, } \\
\text { Saskatchewan }\end{array}$ & $\begin{array}{l}\text { Cropland, Permanent } \\
\text { Cover Program (PCP; } \\
\text { idle tame, tame hayland, } \\
\text { tame pasture) }\end{array}$ & $\begin{array}{l}\text { Were locally abundant within the mixed-grass } \\
\text { region; within this region they were more abundant } \\
\text { in PCP than in cropland, although they were present } \\
\text { in both PCP and cropland; frequency of occurrence } \\
\text { did not differ between PCP sites that were hayed or } \\
\text { used for pasture }\end{array}$ \\
\hline Pleszczynska 1977 & South Dakota & $\begin{array}{l}\text { Idle mixed-grass, tame } \\
\text { hayland }\end{array}$ & $\begin{array}{l}\text { Nested beneath plants such as alfalfa, plains prickly } \\
\text { pear (Opuntia polyacantha), fringed sagewort } \\
\text { (Artemisia frigida), and soapweed yucca (Yucca } \\
\text { glauca) }\end{array}$ \\
\hline Porter and Ryder 1974 & Colorado & Shortgrass pasture & $\begin{array}{l}\text { Preferred to nest in lightly to moderately grazed } \\
\text { pastures }\end{array}$ \\
\hline Rand 1948 & Alberta & $\begin{array}{l}\text { Cropland, idle } \\
\text { shortgrass, shortgrass }\end{array}$ & $\begin{array}{l}\text { Preferred sagebrush and areas of relatively tall, } \\
\text { dense grass or dense ground cover; were absent on }\end{array}$ \\
\hline
\end{tabular}




\begin{tabular}{|c|c|c|c|}
\hline & & pasture & heavily grazed shortgrass prairie \\
\hline $\begin{array}{l}\text { Rotenberry and Wiens } \\
1980\end{array}$ & $\begin{array}{l}\text { Colorado, Kansas, } \\
\text { Montana, } \\
\text { Nebraska, } \\
\text { Oklahoma, Oregon, } \\
\text { South Dakota, } \\
\text { Texas, Washington, } \\
\text { Wisconsin, } \\
\text { Wyoming }\end{array}$ & $\begin{array}{l}\text { Idle mixed-grass, idle } \\
\text { shortgrass, idle } \\
\text { shrubsteppe, idle } \\
\text { tallgrass, montane } \\
\text { meadow }\end{array}$ & $\begin{array}{l}\text { Abundance was correlated positively with litter } \\
\text { depth }\end{array}$ \\
\hline Ryder 1980 & Colorado & Shortgrass pasture & Were more common on lightly grazed areas \\
\hline Shane 1972 & Kansas & $\begin{array}{l}\text { Cropland, idle, sand- } \\
\text { sage grassland, } \\
\text { shortgrass pasture }\end{array}$ & $\begin{array}{l}\text { Nested in areas that had fewer and shorter sand } \\
\text { sagebrush plants (height of } 23 \mathrm{~cm} \text { in occupied areas } \\
\text { compared to } 42 \mathrm{~cm} \text { in unoccupied areas), were less } \\
\text { open ( } 30 \% \text { open area compared to } 44 \% \text { ), and had a } \\
\text { higher percent coverage of forbs ( } 48 \% \text { compared to } \\
30 \% \text { ) than non-nest sites; average vegetation height } \\
\text { at nest sites was } 25 \mathrm{~cm} \text {; successful nests were } \\
\text { adjacent to tall (mean of } 31 \mathrm{~cm} \text { ) vegetation and tall } \\
\text { (mean of } 42 \mathrm{~cm} \text { ) forbs; orientation of the nest } \\
\text { depended upon the vegetation at the nest site }\end{array}$ \\
\hline Shane 2000 & Rangewide & $\begin{array}{l}\text { Cropland, idle mixed- } \\
\text { grass, idle shortgrass, } \\
\text { shrubsteppe }\end{array}$ & $\begin{array}{l}\text { Preferred areas dominated by wheatgrass } \\
\text { (Agropyron spp.), blue grama (Bouteloua gracilis), } \\
\text { needle-and-thread (Stipa comata), and big } \\
\text { sagebrush (Artemisia tridentata); nested on the } \\
\text { ground under shrubs, grasses, or forbs }\end{array}$ \\
\hline Smith and Smith 1966 & Saskatchewan & Mixed-grass pasture & $\begin{array}{l}\text { Nests were placed on the ground in vegetation 18- } \\
61 \mathrm{~cm} \text { tall and usually in western snowberry } \\
\text { (Symphoricarpos occidentalis) }\end{array}$ \\
\hline
\end{tabular}




\begin{tabular}{|c|c|c|c|}
\hline Stewart 1975 & North Dakota & $\begin{array}{l}\text { Idle, idle mixed-grass, } \\
\text { idle tame, tame hayland }\end{array}$ & $\begin{array}{l}\text { Preferred sage-prairie flats along stream valleys or } \\
\text { in lowland draws; often used anthropogenic habitats } \\
\text { such as weedy roadsides, retired cropland planted to } \\
\text { grasses and legumes, weedy fallow fields, and } \\
\text { alfalfa hayfields; nested on the ground at the base of } \\
\text { a low shrub or forb }\end{array}$ \\
\hline Strong 1971 & Colorado & Idle, shortgrass pasture & $\begin{array}{l}\text { Nested in clumps of vegetation in lightly to } \\
\text { moderately grazed grassland; nest success increased } \\
\text { with increased nest cover }\end{array}$ \\
\hline Whittle 1922 & Montana & $\begin{array}{l}\text { Cropland, idle, idle } \\
\text { shortgrass }\end{array}$ & $\begin{array}{l}\text { Nested in weedy areas beneath tumble ringwing } \\
\text { (Cycloloma atriplicifolium) }\end{array}$ \\
\hline Wiens 1970 & Colorado & Shortgrass pasture & $\begin{array}{l}\text { Preferred heavily winter-grazed over heavily } \\
\text { summer-grazed pastures; measurements for } \\
\text { occupied areas were } 81 \% \text { grass cover, } 6 \% \text { forb } \\
\text { cover, } 38 \% \text { litter cover, } 0 \% \text { woody cover, } 3 \% \text { cactus } \\
\text { cover, } 14 \% \text { bare ground, } 0.92 \text { cm vegetation height, } \\
\text { and } 0.42 \mathrm{~cm} \text { litter depth }\end{array}$ \\
\hline Wiens 1973 & $\begin{array}{l}\text { Colorado, } \\
\text { Montana, } \\
\text { New Mexico, } \\
\text { Oklahoma, } \\
\text { South Dakota, } \\
\text { Texas }\end{array}$ & $\begin{array}{l}\text { Idle mixed-grass, idle } \\
\text { shortgrass, mixed-grass } \\
\text { pasture, semidesert } \\
\text { shrubsteppe pasture, } \\
\text { shortgrass pasture, } \\
\text { tallgrass pasture }\end{array}$ & $\begin{array}{l}\text { Avoided heavily summer-grazed sites; mean habitat } \\
\text { values for used areas in heavily winter-grazed sites } \\
\text { were } 82 \% \text { grass cover, } 6 \% \text { forb cover, } 24 \% \text { litter } \\
\text { cover, } 2 \% \text { woody cover, } 1 \% \text { cactus cover, } 16 \% \text { bare } \\
\text { ground, and } 0 \% \text { rock cover; } 361 \text { stems } / \mathrm{m}^{2} \text { forb } \\
\text { density, } 48 \text { stems } / \mathrm{m}^{2} \text { woody plant, and } 137 \\
\text { stems/m² cactus; } 100 \% \text { open sky at ground level; } \\
0.29 \mathrm{~cm} \text { litter depth; } 8.1 \mathrm{~cm} \text { emergent vegetation } \\
\text { height (vegetation that extended above the overall } \\
\text { vegetation canopy), and } 0.5 \mathrm{~cm} \text { effective vegetation } \\
\text { height (height at which a narrow board was } 90 \% \\
\text { obscured by vegetation within } 3 \text { cm of the board) }\end{array}$ \\
\hline
\end{tabular}




\begin{tabular}{|l|l|l|l|}
\hline Wilson 1976 & Kansas & $\begin{array}{l}\text { Cropland, idle mixed- } \\
\text { grass, seeded pasture, } \\
\text { tame hayland }\end{array}$ & $\begin{array}{l}\text { Nests were placed in areas of good visibility } \\
\text { underneath protective plants, such as stubble or } \\
\text { forbs; early nesters used stubble habitat whereas late } \\
\text { nesters placed nests in native grassland on hillsides } \\
\text { with sparse vegetation; nest success was greater in } \\
\text { native grassland and alfalfa than in stubble }\end{array}$ \\
\hline With and Webb 1993 & Colorado & Shortgrass pasture & $\begin{array}{l}\text { Nested in moderately grazed areas; nest sites had } \\
\text { overhanging vegetation; majority of nests were } \\
\text { placed on the north side of vegetation }\end{array}$ \\
\hline Woolfolk 1945 & Montana & Shortgrass pasture & Nested under sagebrush \\
\hline
\end{tabular}

*In an effort to standardize terminology among studies, various descriptors were used to denote the management or type of habitat. "Idle” used as a modifier (e.g., idle tallgrass) denotes undisturbed or unmanaged (e.g., not burned, mowed, or grazed) areas. "Idle" by itself denotes unmanaged areas in which the plant species were not mentioned. Examples of "idle” habitats include weedy or fallow areas (e.g., oldfields), fencerows, grassed waterways, terraces, ditches, and road rights-of-way. "Tame" denotes introduced plant species (e.g., smooth brome [Bromus inermis]) that are not native to North American prairies. "Hayland" refers to any habitat that was mowed, regardless of whether the resulting cut vegetation was removed. "Burned" includes habitats that were burned intentionally or accidentally or those burned by natural forces (e.g., lightning). In situations where there are two or more descriptors (e.g., idle tame hayland), the first descriptor modifies the following descriptors. For example, idle tame hayland is habitat that is usually mowed annually but happened to be undisturbed during the year of the study. 


\section{LITERATURE CITED}

Allen, J. A. 1874. Notes on the natural history of portions of Dakota and Montana Territories, being the substance of a report to the Secretary of War on the collections made by the North Pacific Railroad Expedition of 1873, Gen. D.S. Stanley, Commander. Proceedings of the Boston Society of Natural History 17:33-86.

Baldwin, P. H., J. D. Butterfield, P. D. Creighton, and R. Shook. 1969. Summer ecology of the Lark Bunting. U.S. International Biological Program, Grassland Biome Technical Report 29. Colorado State University, Fort Collins, Colorado. 37 pages.

Baumgarten, H. E. 1968. Lark Bunting. Pages 638-657 in O. L. Austin, Jr., editor. Life histories of North American cardinals, grosbeaks, buntings, towhees, finches, sparrows, and allies, part 2. Dover Publications, Inc., New York, New York.

Bock, C. E., and J. H. Bock. 1987. Avian habitat occupancy following fire in a Montana shrubsteppe. Prairie Naturalist 19:153-158.

Bock, C. E., V. A. Saab, T. D. Rich, and D. S. Dobkin. 1993. Effects of livestock grazing on Neotropical migratory landbirds in western North America. Pages 296-309 in D. M. Finch and P. W. Stangel, editors. Status and management of Neotropical migratory birds. U.S.D.A. Forest Service, General Technical Report RM-229.

Cameron, E. S. 1908. The birds of Custer and Dawson counties, Montana. Auk 25:39-56.

Creighton, P. D. 1971. Nesting of the Lark Bunting in northcentral Colorado. U.S. International Biological Program, Grassland Biome Technical Report 68. Colorado State University, Fort Collins, Colorado. 17 pages.

Creighton, P. D. 1974. Habitat exploitation by an avian ground-foraging guild. Ph.D. dissertation. Colorado State University, Fort Collins, Colorado. 154 pages.

Davis, S. K. 1994. Cowbird parasitism, predation, and host selection in fragmented grasslands of southwestern Manitoba. M.S. thesis. University of Manitoba, Winnipeg, Manitoba. 77 pages.

Davis, S. K., D. C. Duncan, D. A. Anstey, and M. Skeel. 1997. Habitat selection of grassland songbirds in southern Saskatchewan. Unpublished report to the Saskatchewan Wetland Conservation Corporation, Regina, Saskatchewan. 31 pages.

Davis, S. K., and S. G. Sealy. 2000. Cowbird parasitism and nest predation in fragmented grasslands of southwestern Manitoba. Pages 220-228 in J. N. M. Smith, T. L. Cook, S. I. Rothstein, S. K. Robinson, and S. G. Sealy, editors. Ecology and management of cowbirds and their hosts. University of Texas Press, Austin, Texas. 
Dunn, L. E. 1986. Nesting of Lark Bunting in Harper and Beaver counties. Bulletin of the Oklahoma Ornithological Society 19:32.

Faanes, C. A., and G. R. Lingle. 1995. Breeding birds of the Platte River Valley of Nebraska. Jamestown, ND: Northern Prairie Wildlife Research Center home page. http://www.npwrc.usgs.gov/resource/distr/birds/platte/platte.htm (Version 16JUL97).

Fautin, R. W. 1975. The terrestrial vertebrate fauna of the Atlantic Richfield Company’s Black Thunder Coal lease property in Campbell County, Wyoming. Pages 635-650 in Fort Union Coal Field Symposium.

Finch, D. M., S. H. Anderson, and W. A. Hubert. 1987. Habitat suitability index models: Lark Bunting. U.S. Fish and Wildlife Service, Biological Report 82. 16 pages.

Friedmann, H. 1963. Host relations of the parasitic cowbirds. U.S. National Museum Bulletin 233:1-276.

Friedmann, H., L. F. Kiff, and S. I. Rothstein. 1977. A further contribution to knowledge of the host relations of the parasitic cowbirds. Smithsonian Contributions to Zoology 235:1-75.

Giezentanner, J. B. 1970. Avian distribution and population fluctuations on the shortgrass prairie of north central Colorado. M.S. thesis. Colorado State University, Fort Collins, Colorado. 113 pages.

Giezentanner, J. B., and R. A. Ryder. 1969. Avian distribution and population fluctuations at the Pawnee site. U.S. International Biological Program, Grassland Biome Technical Report 28. Colorado State University, Fort Collins, Colorado. 29 pages.

Griebel, R. L., S. L. Winter, and A. A. Steuter. 1998. Grassland birds and habitat structure in sandhills prairie management using cattle or bison plus fire. Great Plains Research 8:255-268.

Hibbard, E. A. 1965. Comments on the distribution and abundance of the Lark Bunting and other prairie fringillids in Minnesota and North Dakota. Loon 37:70-72.

Hill, R. A. 1976. Host-parasite relationships of the Brown-headed Cowbird in a prairie habitat of west-central Kansas. Wilson Bulletin 88:555-565.

Johnsgard, P. A. 1979. Birds of the Great Plains. University of Nebraska Press, Lincoln, Nebraska. 539 pages.

Johnsgard, P. A. 1980. A preliminary list of the birds of Nebraska and adjacent Plains states. University of Nebraska, Lincoln, Nebraska. 156 pages.

Johnson, A. R. 1981. Habitat utilization by Lark Buntings (Calamospiza melanocorys) in a cold desert mixed shrub community. M.S. thesis. Brigham Young University, Provo, Utah. 16 pages. 
Johnson, D. H., and M. D. Schwartz. 1993a. The Conservation Reserve Program and grassland birds. Conservation Biology 7:934-937.

Johnson, D. H., and M. D. Schwartz. 1993b. The Conservation Reserve Program: habitat for grassland birds. Great Plains Research 3:273-295.

Kantrud, H. A. 1981. Grazing intensity effects on the breeding avifauna of North Dakota native grasslands. Canadian Field-Naturalist 95:404-417.

Kantrud, H. A., and R. L. Kologiski. 1982. Effects of soils and grazing on breeding birds of uncultivated upland grasslands of the northern Great Plains. U.S. Fish and Wildlife Service, Wildlife Research Report 15. 33 pages.

Kantrud, H. A., and R. L. Kologiski. 1983. Avian associations of the northern Great Plains grasslands. Journal of Biogeography 10:331-350.

Klimkiewicz, M. K., and A. G. Futcher. 1987. Longevity records of North American birds: Coerebinae through Estrildidae. Journal of Field Ornithology 58:318-333.

Koford, R. R., B. S. Bowen, J. T. Lokemoen, and A. D. Kruse. 2000. Cowbird parasitism in grassland and cropland in the northern Great Plains. Pages 229-235 in J. N. M. Smith, T. L. Cook, S. I. Rothstein, S. K. Robinson, and S. G. Sealy, editors. Ecology and management of cowbirds and their hosts. University of Texas Press, Austin, Texas.

Knapton, R. W. 1979. Birds of the Gainsborough-Lyleton region. Saskatchewan Natural History Society Special Publication 10. 72 pages.

Langdon, R. M. 1933. The Lark Bunting. Bird-Lore 35:139-142.

Lokemoen, J. T., and J. A. Beiser. 1997. Bird use and nesting in conventional, minimumtillage, and organic cropland. Journal of Wildlife Management 61:644-655.

Maher, W. J. 1974. Matador Project: Birds II. Avifauna of the Matador area. Canadian Committee for the International Biological Programme, Matador Project, Technical Report 58. University of Saskatchewan, Saskatoon, Saskatchewan. 31 pages.

McEwen, L. C., and J. O. Ells. 1975. Field ecology investigations of the effects of selected pesticides on wildlife populations. U.S. International Biological Program, Grassland Biome Technical Report 289. Colorado State University, Fort Collins, Colorado. 36 pages.

McEwen, L. C., C. E. Knittle, and M. L. Richmond. 1972. Wildlife effects from grasshopper insecticides sprayed on short-grass range. Journal of Range Management 25:188-194.

McMaster, D. G., and S. K. Davis. 1998. Non-game evaluation of the Permanent Cover Program. Unpublished report. Saskatchewan Wetland Conservation Corporation, Regina, Saskatchewan. 75+ pages. 
National Geographic Society. 1987. Field guide to the birds of North America, second edition. National Geographic Society, Washington, D.C. 464 pages.

Pleszczynska, W. K. 1977. Polygyny in the Lark Bunting. Ph.D. dissertation. University of Toronto, Toronto, Ontario. 119 pages.

Pleszczynska, W. K., and R. I. C. Hansell. 1980. Polygyny and decision theory: testing of a model in Lark Buntings (Calamospiza melanocorys). American Naturalist 116:821-830.

Porter, D. K., and R. A. Ryder. 1974. Avian density and productivity studies and analyses on the Pawnee site in 1972. U.S. International Biological Program, Grassland Biome Technical Report 252. Colorado State University, Fort Collins, Colorado. 77 pages.

Rand, A. L. 1948. Birds of southern Alberta. National Museum of Canada, Ottawa, Canada. Bulletin no. 111. Biological series, no. 37. 105 pages.

Rotenberry, J. T., and J. A. Wiens. 1980. Habitat structure, patchiness, and avian communities in North American steppe vegetation: a multivariate analysis. Ecology 61:1228-1250.

Ryder, R. A. 1972. Avian population studies on the Pawnee Site, 1968-1971. U. S. International Biological Program, Grassland Biome Technical Report 171. Colorado State University, Fort Collins, Colorado. 62 pages.

Ryder, R. A. 1980. Effects of grazing on bird habitats. Pages 51-66 in R. M. DeGraff and N. G. Tilghman, editors. Management of western forests and grasslands for nongame birds. U.S.D.A. Forest Service, General Technical Report INT-86.

Sealy, S. G. 1999. Cowbird parasitism on Lark Buntings: frequency, acceptance, and fledging. Journal of Field Ornithology 70:182-186.

Shaffer, J. A., C. M. Goldade, M. F. Dinkins, D. H. Johnson, L. D. Igl, and B. R. Euliss. 2003. Brown-headed Cowbirds in grasslands: their habitats, hosts, and response to management. Prairie Naturalist 35:146-186.

Shane, T. G. 1972. The nest site selection behavior of the Lark Bunting, Calamospiza melanocorys. M.S. thesis. Kansas State University, Manhattan, Kansas. 55 pages.

Shane, T. G. 1974. Nest placement by Lark Buntings. Bird Watch 2:1-3.

Shane, T. G. 2000. Lark Bunting (Calamospiza melanocorys). In A. Poole and F. Gill, editors. The birds of North America, No. 542. The Birds of North America, Inc., Philadelphia, Pennsylvania.

Smith, H., and J. Smith. 1966. A breeding bird survey on uncultivated grassland at Regina. Blue Jay 24:129-131. 
Stewart, R. E. 1975. Breeding birds of North Dakota. Tri-College Center for Environmental Studies, Fargo, North Dakota. 295 pages.

Strong, M. A. 1971. Avian productivity on the shortgrass prairie of northcentral Colorado. M.S. thesis. Colorado State University, Fort Collins, Colorado. 70 pages.

Tout, W. 1902. Ten years without a gun. Proceedings of the Nebraska Ornithological Union 3:42-45.

Whittle, C. L. 1922. Miscellaneous bird notes from Montana. Condor 24:73-81.

Wiens, J. A. 1970. Avian populations and patterns of habitat occupancy at the Pawnee site, 1968-1969. U.S. International Biological Program, Grassland Biome Technical Report 63. Colorado State University, Fort Collins, Colorado. 57 pages.

Wiens, J. A. 1971. Avian ecology and distribution in the comprehensive network, 1970. U.S. International Biological Program, Grassland Biome Technical Report 77. Colorado State University, Fort Collins, Colorado. 49 pages.

Wiens, J. A. 1973. Pattern and process in grassland bird communities. Ecological Monographs 43:237-270.

Wilson, J. K. 1976. Nesting success of the Lark Bunting near the periphery of its breeding range. Kansas Ornithological Society Bulletin 27:13-22.

With, K. A., and D. R. Webb. 1993. Microclimate of ground nests: the relative importance of radiative cover and wind breaks for three grassland species. Condor 95:401-413.

Woolfolk, E. J. 1945. Some observations of Lark Buntings and their nests in eastern Montana. Condor 47:128. 